\title{
ANALYSIS OF RAILWAY FATALITIES IN VISAKHAPATNAM- AN AUTOPSY-BASED STUDY
}

\author{
Vadde Chandra Sekhar1, Sugnan Bandaru², Rama Krishna Pedada ${ }^{3}$
}

${ }_{1}^{1}$ Associate Professor, Department of Forensic Medicine and Toxicology, Andhra Medical College, Visakhapatnam, Andhra Pradesh, India.

2Senior Resident, Department of Forensic Medicine and Toxicology, Andhra Medical College, Visakhapatnam, Andhra Pradesh, India. ${ }_{3}^{3}$ Assistant Professor, Department of Forensic Medicine and Toxicology, Andhra Medical College, Visakhapatnam, Andhra Pradesh, India.

ABSTRACT
BACKGROUND
The deaths in railway workers were mentioned by Modi. ${ }^{1}$ Bernard Knight. ${ }^{2}$ Shapiro ${ }^{3}$ noticed $9 \%$ of incidence and about $10 \%$
incidence was noted by Davis $\mathrm{GG}^{4}$ among the workers who succumbed to railway injuries. Incidence of railway fatalities is
increasing year by year in and around Visakhapatnam. Department of Forensic Medicine and Toxicology, Andhra Medical College/
King George Hospital, Visakhapatnam received 76 cases in 2010, 79 cases in 2011, 96 cases in 2012, 109 cases in 2013 and 118
cases in 2014.
The aim of this study is to determine the pattern of injuries and identify the common medicolegal problems associated with
identity of deceased and cause of deaths at Andhra Medical College/King George Hospital Mortuary, Visakhapatnam city.

\section{MATERIALS AND METHODS}

This is a descriptive study of all railway deaths, which are seen in Mortuary of Department of Forensic Medicine and Toxicology, Andhra Medical College/King George Hospital, Visakhapatnam City over a period of one year, i.e. 01 January 2015 to 31 December 2015.

\section{RESULTS}

Railway deaths are uncommon, mostly accidental fall or trespassers and few are suicidal. A total of 1747 autopsies were done during the period. Ninety-two cases representing $5.26 \%$ of all bodies received by the mortuary were deaths due to railway fatalities. Most of the cases are accidental (72.83\%) and suicidal (17.34\%), rest of the $4.35 \%$ are undetermined manner due to putrefaction mutilated body parts. Male-to-female ratio is 8.25: 1. Peak incidence was observed in the age group of 21-40 years.

\section{CONCLUSION}

This study shows the pattern of railway injury deaths in Visakhapatnam and suggestions to establish identity of unknown persons and possible preventive measures to avoid or decrease railway fatalities.

\section{KEY WORDS}

Railway Injuries, Polytrauma, Manner of Death, Identity of Unknown.

HOW TO CITE THIS ARTICLE: Sekhar VC, Bandaru S, Pedada RK. Analysis of railway fatalities in Visakhapatnam- an autopsybased study. J. Evolution Med. Dent. Sci. 2018;7(28):3170-3173, DOI: 10.14260/jemds/2018/713

\section{BACKGROUND}

Injuries and deaths due to accidents are not escapable in modern ways of living. The accident deaths are mostly due to road traffic accidents, but deaths due to railway fatalities are not negligible, especially where railway traffic is higher. Indian Railway is the largest railway system in the world under a single management. Railway accidents occupied an important role in the medical and legal disclosures on trauma and traumatic disorders.

The deaths in railway workers were mentioned by Modi ${ }^{1}$ and Bernard Knight. ${ }^{2}$ Shapiro ${ }^{3}$ noticed $9 \%$ of incidence and about $10 \%$ incidence was noted by Davis $\mathrm{GG}^{4}$ among the workers who succumbed to railway injuries.

'Financial or Other Competing Interest': None.

Submission 31-05-2018, Peer Review 24-06-2018,

Acceptance 01-07-2018, Published 09-07-2018.

Corresponding Author:

Dr. Vadde Chandra Sekhar,

Associate Professor,

Department of Forensic Medicine and Toxicology,

Andhra Medical College, Visakhapatnam-530002,

Andhra Pradesh, India.

E-mail:vcs4904@gmail.com

DOI: $10.14260 /$ jemds $/ 2018 / 713$
Incidence of railway fatalities is increasing year by year in and around Visakhapatnam. Department of Forensic Medicine and Toxicology, Andhra Medical College/ King George Hospital, Visakhapatnam received 76 cases in 2010, 79 cases in 2011, 96 cases in 2012, 109 cases in 2013 and 118 cases in 2014 .

\section{MATERIALS AND METHODS}

This is a descriptive study. The cases which were selected for this study are those brought by Railway Police for postmortem examination to modern mortuary, King George Hospital/ Andhra Medical College, Visakhapatnam from $1^{\text {st }}$ January 2015 to $31^{\text {st }}$ December 2015. The total number of cases that were received as a consequence of railway accidents was 92 .

The data was collected from visiting the scene of incidence, inquest reports, history revealed from relatives, friends etc. of the deceased, where the identity was established and hospital case-sheets (in cases which were admitted in the hospital). The data was tabulated in a pretested proforma and the results were analysed using appropriate statistical methods. 
RESULTS

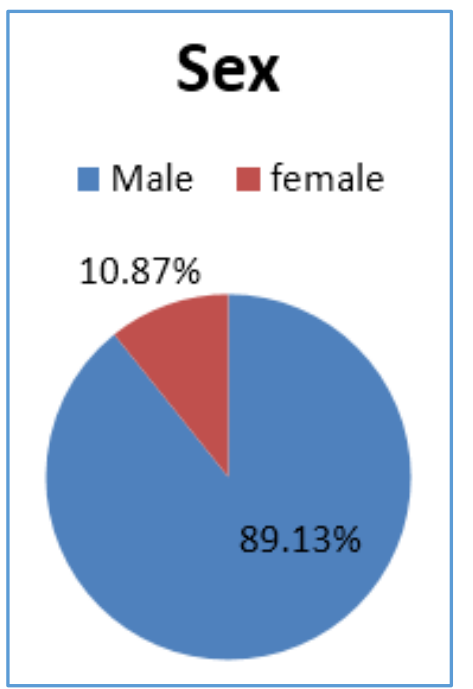

Pie Diagram 1. Sex Wise distribution of Cases

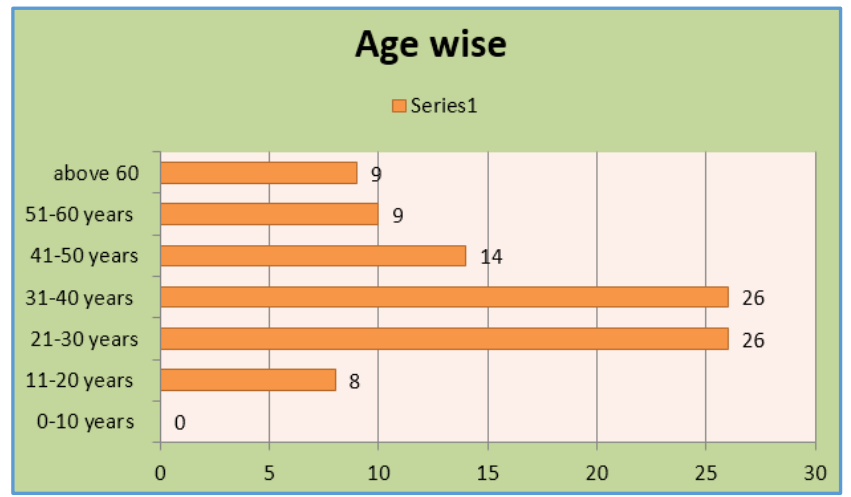

Bar Diagram 1. Age Wise distribution of Cases

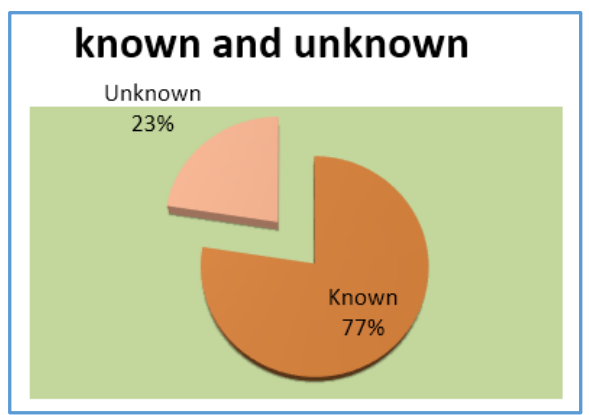

Pie Diagram 2. Identity Wise (Known/ Unknown)

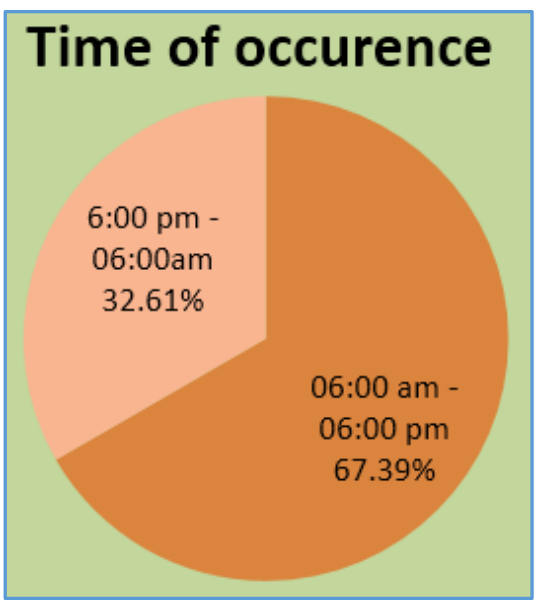

Pie Diagram 3. Time of Occurrence

\section{Place of Occurence}

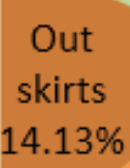

Station limits

Town limits $22.83 \%$

$63.04 \%$

Pie Diagram 4. Place of Occurrence

\begin{tabular}{|c|c|}
\hline Cause of Death & No. of Cases \\
\hline Decapitation & 13 \\
\hline Head injury & 31 \\
\hline Multiple injuries & 22 \\
\hline Crush injury chest & 4 \\
\hline Crush injury abdomen & 4 \\
\hline Transection of spine excluding decapitation & 6 \\
\hline Crush injury limbs & 6 \\
\hline Natural death & 5 \\
\hline Suffocation (fall of iron ore) & 1 \\
\hline Table 1. Cause of Death Wise distribution of Cases
\end{tabular}

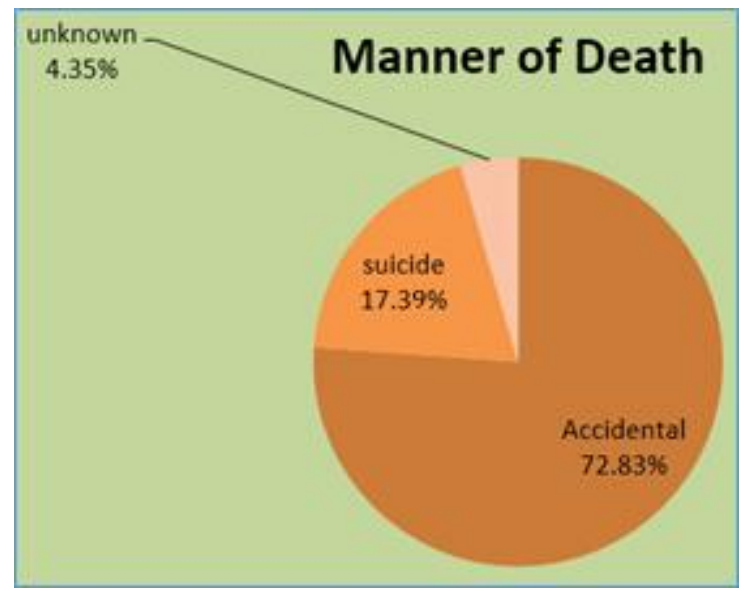

Pie Diagram 5

\begin{tabular}{|c|c|}
\hline Nature of Incident & No. of Cases \\
\hline Fall from Train & 38 \\
\hline Trespasser & 25 \\
\hline Nature call & 4 \\
\hline Walking towards & 2 \\
\hline Lying on track & 13 \\
\hline Unknown & 4 \\
\hline Natural death & 5 \\
\hline Suffocation & 1 \\
\hline Table 2. Deaths based on Nature of Incident
\end{tabular}




\section{DISCUSSION}

During the study period (January 2015 to December 2015) one year there were 92 cases of fatal railway injuries comprising $5.26 \%$ out of 1747 autopsies done at Andhra Medical College, Visakhapatnam. It is observed that out of 92 cases, 82 victims (89.13\%) under this study were male and $10(10.87 \%)$ victims were female as shown in Pie Diagram 1.

It is observed from the Bar Diagram 1 that the highest number of victims were in the age group of 21 to $40 \mathrm{yrs}$. and contained a total of 52 cases, comprising $56.52 \%$ of total number of cases studied. This was followed closely by the group of 41 - 50 yrs., which contained 14 (15.22\%) and the other group 51 - 60 yrs. with 9 cases $(9.78 \%)$, above 60 yrs. with 9 cases $(9.78 \%)$, least group 11 - 20 yrs. 8 cases (8.69\%).

As evident from the Pie Diagram 2 unknown cases brought as railway deaths amounted to $23 \%(n=21)$, which is significant. Reason being mutilation of bodies beyond recognition state; passengers from other states travelling to Visakhapatnam for business, employment, uneducated, unemployed with no proper identification documents/ cards in their belongings. According to statistics released by NCRB, in 2013 it was 1520 and 2014 it was 1667 number of unknown bodies recovered by police of Andhra Pradesh. This shows that the unknown/ unidentified bodies are increasing year by year. This report predicts that among all unidentified bodies, $60 \%$ of them were recovered by government railway police. Though Andhra Pradesh stands in $8^{\text {th }}$ place, this percentage is much highest (5.44\%) in our centre among all unknown bodies, which results in many families to suffer from presumption of death/ survivorship of their beloved.

The time of accident was split into 12 -hour intervals, i.e. day time 6 am to $6 \mathrm{pm}$ and night time $6 \mathrm{pm}$ to $6 \mathrm{am}$. Perusal of Pie Diagram 3, about $67.39 \%(n=62)$ of railway fatalities occurred in daytime only. This can be attributed to active working time of people, busy public roaming at railway crossings in stations, outskirts and town limits; walking along platforms and railway tracks, mind-set of individuals who look for opportune time as well as to avoid eyes of their family and relatives to commit suicide. This diagram shows $32.61 \%$ of cases, i.e. 30 numbers were from dusk to dawn, i.e. $6 \mathrm{pm}$ to 6 am.

Out of 92 cases, 58 (63.04\%) cases occurred within town limits followed by $21(22.83 \%)$ at station limits and 13 $(14.13 \%)$ in outskirts. The majority in station limits and town limits is due to crowd walking along platforms, crossing railway tracks in urgency of their work not using foot overs, accessible places for public to commit suicides. The least percentage of cases i.e. $13(14.13 \%)$ compared to older studies is due to proper railway crossings/ gates, construction of flyovers/ bridges at railway crossings etc. due to urbanisation of Visakhapatnam. ${ }^{5}$

For our convenience, we have tabulated causes of death as mentioned in the table. Among railway fatalities, head injury is the major contributor for death accounting for 31 cases (33.69\%). 13 cases were reported as decapitation and 6 cases with other level transection. Crush injury chest and crush injury abdomen cases were equal in number, i.e. 4 cases each. There are 6 cases where persons died of crush injury limbs. The $2^{\text {nd }}$ most frequent cause of death in table is multiple injuries, which include combination of any of the above causes of death excluding transection. There are 5 cases of natural deaths of which 2 of respiratory pathology, 2 of coronary artery disease and 1 of hepatic failure. One case of suffocation due to falling of iron ore while unloading wagon on track.

On the basis of inquest reports, eyewitness, driver of train statement, presence of suicide notes and postmortem findings manner of death was ascertained. It was found that majority of cases were accidental in nature followed by suicides and natural deaths. Incidence of railway fatalities from accidental manner were $67(72.83 \%)$ cases. When it comes to suicides, 16 cases were reported amounting to $17.39 \%$ which indicates increasing tendency of people resorting to commit suicide by putting themselves under or against a moving train. Natural deaths in this study amounted for $5.43 \%$. Manner of death was not made out in $4.35 \%$ of cases, i.e. 4 numbers due to inadequate information given by railway police, significant percentage of unknown or mutilation of dead body by moving train. No case was reported with homicidal manner. This statistics of manner of death matching with other studies.6,7,8

Majority of railway deaths were by people falling from train while boarding, getting down and running train. In our study, deaths due to fall from train are 38 in number amounting to $41.30 \%$ of all cases. Second common people at risk are trespassers ${ }^{9}$ contributing to $27.17 \%$ (25 cases). There were 13 cases of suicide by lying on track before running train. Four people suffered death while sitting for nature calls and 1 case suffocation due to fall of iron ore. In 4 cases, nature of incident was not ascertained.

\section{CONCLUSION}

In the present study, majority of victims were males. Male to female ratio was 8.25:1. The peak incidence was noted in the $2^{\text {nd }}$ to $4^{\text {th }}$ decade. Majority of cases belonged to urban areas. Most of the victims were manual labourers, travelling, moving and crossing near railway tracks. Most of the occurrences were in early hours of the day, between $6 \mathrm{AM}$ and $9 \mathrm{AM}$.

\section{Suggestions}

1. Online registration of unknown bodies with identifying features, photographs etc., accessible to all public on daily basis.

2. Maintaining web portal for access to public to match their missing persons.

3. Interstate communication about missing persons and unknown bodies of their jurisdiction.

4. Railway safety gets prominence in each year railway budget, but to no avail. New technology is introduced every year and speed of train is increasing, which necessitates robust safety measures to make train journey safe. Railway ministry is trying to get safety measures available to make rail journey safe.

5. Rail accident investigation branch to be established, independently investigates accidents to improve railway safety and inform the ministry and public.

6. Public education and awareness programs directed at school age children, in particular with emphasis on the risks associated with trespassing on railway lines have to be made. 


\section{Jemds.com}

7. Fencing the railway tracks to prevent trespassing might look idealistic.

\section{REFERENCES}

[1] Modi JP. Injuries by mechanical violence. Chapter - 10. In: Franklin CA. edr. Modi's text book of medical jurisprudence and toxicology. $21^{\text {st }}$ edn. Bombay: N.M Tripathi 1988: p. 203.

[2] Knight B. Knight's Forensic Pathology. $3^{\text {rd }}$ edn. India: 2004.

[3] Shapiro MJ, Luchtefeld WB, Durham RM, et al. Traumatic train injuries. Am J Emerg Med 1994;12(1):92-3.

[4] Davis GG, Alexander CB, Brissie RM. A 15-year review of railway-related deaths in Jefferson Country, Alabama. Am J Forensic Med Pathol 1997;18(4):363-8.

[5] Railway safety facts: Safety and Security. Railway Safety Director, Rail safety programme March, Railway stress passer occurrence Nov. 1996.

\section{Original Research Article}

[6] Deisenhammer EA, Kemmler G, De Col C, et al. Railroad suicides and attempted suicides in Austria 1990-1994. Extending the hypothesis mass media transmission of suicidal behaviour. Nervenarzt 1997;68(1):67-73.

[7] Sahoo PC, Kar SM. Pattern of injuries in railway death: a retrospective study in MDLG medical college, Bharampur. Journal of Indian Academy of Forensic Medicine 1998;2(3):67-8.

[8] Paul PB, Batabyal S, Bose TK, et al. Railway fatalities - a retrospective study. Journal of Indian Academy of Forensic Medicine 2006;24(3).

[9] Subrahmanyam BV. Modi's Medical jurisprudence and toxicology. Traffic injuries. 22nd edn. 1999: p. 399-400. 